Article

\title{
Anticipatory Non-Green-Phenomena Determination for Designing Eco-Design Products
}

\author{
Hsin Rau ${ }^{1, *}$, Mary Deanne M. Lagapa ${ }^{2}$ and Po-Hsun Chen ${ }^{1}$ \\ 1 Department of Industrial and Systems Engineering, Chung Yuan Christian University, Chungli District, \\ Taoyuan City 32023, Taiwan; leo30420119@gmail.com \\ 2 Department of Industrial Engineering and Service Engineering Management, Mapúa University, Intramuros, \\ Manila 1002, Philippines; deah_lagapa@yahoo.com \\ * Correspondence: hsinrau@cycu.edu.tw; Tel.: +886-(3)-2654417
}

check for updates

Citation: Rau, H.; Lagapa, M.D.M.;

Chen, P.-H. Anticipatory

Non-Green-Phenomena

Determination for Designing

Eco-Design Products. Sustainability

2021, 13, 621. https://doi.org/

$10.3390 /$ su13020621

Received: 10 November 2020

Accepted: 6 January 2021

Published: 11 January 2021

Publisher's Note: MDPI stays neutral with regard to jurisdictional clai$\mathrm{ms}$ in published maps and institutional affiliations.

Copyright: $(\odot 2021$ by the authors. Licensee MDPI, Basel, Switzerland. This article is an open access article distributed under the terms and conditions of the Creative Commons Attribution (CC BY) license (https:// creativecommons.org/licenses/by/ $4.0 /)$.

\begin{abstract}
The number of consumers with green awareness have grown these days and as a result they have turned to purchase eco-friendly products. For this reason, this study aims to propose a method for eco-design based on the anticipatory failure determination method to develop eco-design products. By using eco-design concepts adopted from the World Business Council for Sustainable Development, the process will limit the failures and issues related to environmental impact in product design. The proposed method for eco-design product in this study follows the following procedure. First, we analyze product failure. Second, we propose the determination of the nongreen phenomenon of the failure. Thirdly, we integrate the intensified non-green phenomenon to generate non-green hypotheses and fourthly, we eliminate each non-green phenomenon hypothesis by introducing the contradiction matrix of TRIZ for obtaining solutions. Finally, we assess alternative eco-design solutions by evaluation. To verify the practicality of the new procedure, a washing machine is used as an example for illustration.
\end{abstract}

Keywords: anticipatory failure determination; eco-design; TRIZ

\section{Introduction}

Nowadays, consumers, manufacturers, procurers and even governments are more aware of environmentally friendly products, tasks and policies [1-5]. According to Hozik [6], the rate of Millennials willing to pay more for environmentally conscious products increased from 55\% in 2014 to $72 \%$ in 2015. Curtin [7] had a similar report and stated that while $66 \%$ of global consumers were willing to pay more for sustainable goods (which included environmental, social and economic concerns [8-10]; however, this study focuses on environmentally friendly products or eco-design products more), a full $73 \%$ of Millennials (those born from year 1977 to 1995) were. According to Jezerc [11] from First Insight, Inc., 54\% of Generation Z (born 1995-2012) were willing to spend an incremental $10 \%$ or more on sustainable products, versus $50 \%$ of Millennials (1980-1994), 34\% of Generation X (1965-1979), 23\% of Baby Boomers (1946-1964) and 36\% of the Silent Generation (1928-1945). Actually, younger people have more expectations for eco-design products and various people of different ages also have a certain percentage to support them. Therefore, environmentally related concepts should be considered when developing products [11,12] The World Business Council for Sustainable Development [13] pointed out that companies should consider environmentally friendly aspects when developing products and change their processes by applying environmentally related actions. Eco-design is important in the manufacturing industry and several design methods and tools have been developed to support eco-design [14].

In this study, important requirements will be identified for supporting the eco-design of a product. The important requirements of eco-design are minimizing resource use (such as energy efficiency and water consumption, etc.) [15], not damaging the environment [16], 
etc. Moreover, Eltayeb et al. [17] mentioned basic eco-design activities, including design for reduction or elimination of environmentally hazardous materials, design for reuse, design for recycling, design for remanufacturing and design for resource efficiency, which can be derived for design requirements. In addition, full coverage of requirements for eco-design should be considered during the product life cycle stages $[8,13,18]$ : extraction and processing of raw materials, manufacturing, transportation/distribution, use/reuse/maintenance and disposal/waste recovery stages. When the compliance of any of these requirements or regulations from different product life cycle stages fails, people will pay more attention to it. We call this kind of failure the non-green phenomenon, which means that a failure phenomenon occurs. This failure happens due to failures in the regulation of the eco-design or green design requirements in different product life cycle stages. This study will propose a design process to avoid these failures.

On the other hand, failures have always been a problem whether in product, system or even process design. Their increasing frequency and severity cause human suffering and damage to companies. The Anticipatory Failure Determination (AFD) is an efficient and effective method for analyzing, predicting and eliminating failures in systems, products and processes [19]. It is a cost-effective method of analyzing and predicting failures in products and processes. It guides users in documenting the situation, formulating related problems, developing hypotheses, verifying potential failure scenarios and finding solutions to prevent or eliminate the problems [20].

There are many case studies to illustrate AFD, and the following are some examples. Proseanic et al. [21] discussed the results of the AFD application in solving a hitching/ringing problem in an engine. Sunday [22] integrated the axiomatic design method with AFD to solve failure problems. Wang and Qiu [23] used the AFD method to find the failure conditions of an electrical motorcycle. Although AFD has been used in many studies, few studies use AFD for eco-design. For this reason, this study finds an opportunity to pursue research integrating AFD and eco-design elements for developing eco-design products.

This study aims to develop a method for green product design based on the principle of the AFD method and TRIZ tools. TRIZ is an inventive problem-solving theory and its tools will work with the AFD method to provide innovative solutions to help designers eliminate non-green phenomena in the product design, which will let the product comply with the requirements of eco-design. The rest of the paper is structured as follows: Section 2 gives the literature review, Section 3 details the methodology proposed in this study, Section 4 gives a washing machine design case study to demonstrate the practically of the method and lastly Section 5 concludes the paper.

\section{Literature Review}

In this section, we will review literature under the following subjects: TRIZ, AFD and eco-design.

\subsection{TRIZ}

TRIZ is a Russian language acronym for Teoriya Resheniya Izobreatatelskikh Zadatch. Translated into English it means "The Theory of Inventive Problem Solving". TRIZ is a theory invented by G.S. Altshuller and his colleagues between 1946 and 1985 [24]. TRIZ is a problem-solving method based on logic and data, not intuition, which accelerates a project team's ability to solve problems creatively [25]. Several TRIZ tools now available in literature including Function and Attribute Analysis (FAA), Cause Effect Chain Analysis (CECA), Contradiction Matrix, Inventive Principles, S-Field, Trimming, Trends, Subversion Analysis, etc. However, this study will be using two TRIZ tools which are 40 inventive principles and a contradiction matrix. The TRIZ implementation process generally involves a series of steps, from a specific problem to the model of the problem via the innovation tool of TRIZ to obtain the model of solutions, so that a specific solution can be developed, as shown in Figure 1. 


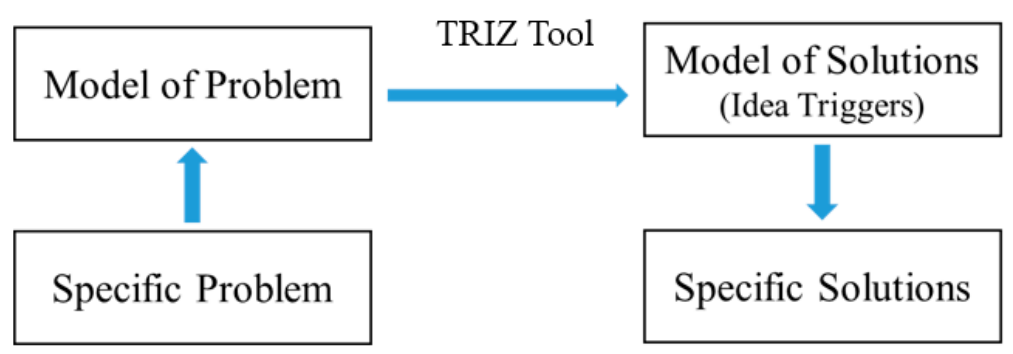

Figure 1. TRIZ implementation process [24].

\subsection{Anticipatory Failure Determination}

The anticipatory failure determination method was developed by Zlotin and Zusman [26]. It is based on the concepts that were called "subversion analysis" in earlier TRIZ work by Zlotin, Zusman, Altshuller, and Filatov [27,28] and Kaplan [29]. With the knowledge of how to subvert the design, the product designer can make the design better, so that the failures cannot happen [30]. The main objective of AFD is to "identify and bring to awareness, potential scenarios that could lead to systems and operations failure, so that they may be fixed before they actually occur" [13,31]. The AFD system consists of two modules: failure analysis of previous failures and prediction of failures that might occur in the future [15]. Ungvari [30] compared AFD with FMEA (Failure Mode and Effect Analysis) and noted that AFD differed from traditional failure analysis in transforming the idea of preventing failure into inventing and creating failures. Proseanic et al. [26] applied AFD to the analysis of the car engine, noticed that using AFD significantly reduced the time of brainstorming and increased the efficiency of the team. In addition, Chybowski et al. [32] applied three elements of the AFD method (AFD-1, AFD-2, and AFD-3) at the concept formulation stage of a system's development for improving the technology readiness level. Most of the studies on AFD focus on solving the technical problems of products. This study will consider combining AFD with eco-design concepts. The concept of eco-design innovation has a lot of room for development, so applying other TRIZ tools will also contribute the improvement of the development of an eco-design product.

\subsection{Eco-Design}

Ecological design (Eco-design), also known as environmental design or green design, is an approach to designing products or processes that considers environmental impacts of the product during its whole life cycle [33]. An environmentally friendly technology leads to a reduction in the consumption of materials and energy. Andrae et al. [34] discussed that consumer electronics industry has a motivation on branding and making the eco-friendly image to respond to the increasing market share among the eco-aware consumers. In addition, Ferrendier et al. [35] mentioned that $70 \%$ to $80 \%$ of the development cost for most products is decided in early design phases. To achieve sustainable development goals, it is necessary to improve environmental efficiency and make good use of environmental resources.

In eco-design, the environment is given the same status as more traditional industrial values such as profit, functionality, aesthetics, ergonomics, image and overall quality [35]. Clark et al. [36] stated that having an eco-friendly material is one of the concepts that can help inspire new product design. Using waste as a valuable resource in the manufacturing will reduce harm on the environment. To save energy and avoid the abuse of materials, the design needs to consider the extension of product life, and implement green design concept and principles [37]. Besides applying to product design, the concept of eco-friendly can also be applied to other areas, such as production [38,39], packaging [40], ICT innovation [41], construction [42-44] and scrap tire handling [45].

According to DeSimone and Popoff [12], environmental-related concepts should be considered when developing products. According to Kibert [46], the World Business Council for Sustainable Development (WBCSD) points out that companies should consider 
environmentally friendly aspects when developing products, and change processes by applying environmental-related actions. From a product life point of view, in 1991, WBCSD proposed seven eco-efficiency elements [13]: (1) reduce the material intensity of its goods and services, (2) reduce the energy intensity of its goods and services, (3) reduce the dispersion of any toxic materials, (4) enhance the recyclability of its materials, (5) maximize the sustainable use of renewable resources, (6) extend the durability of its products, and (7) increase the service intensity of its goods and services. These seven elements concern with three following broad objectives: (1) reducing the consumption of resources, (2) reducing the impact on nature, and (3) increasing product or service value.

Compared with the researches $[8,13,17]$ in the literature, this study will consider the above seven eco-efficiency elements as eco-design requirements in the product design process, due to their originality and coming from WBCSD. When a failure or problem occurs against any of these requirements, a non-green phenomenon will be raised for the treatment of the AFD method.

\section{Methodology}

This study develops a problem-solving method based on AFD. This process can be done through analysis of the current products' non-green phenomena using AFD's reverse thinking by considering eco-design concepts. TRIZ problem-solving tool is used to solve the problem and determine the solution.

\subsection{Non-Green Phenomenon}

As discussed in the literature, WBCSD proposed seven eco-friendly elements or ecodesign requirements, as shown in the following, and they can be presented in a shorter form in the parenthesis [13,47]:

(1) Reduce the material intensity of its goods and services (Reduce material intensity)

(2) Reduce the energy intensity of its goods and services (Energy intensity minimized)

(3) Reduce the dispersion of any toxic materials (Dispersion of toxic substances is reduced)

(4) Enhance the recyclability of its materials (Undertake recycling)

(5) Maximize the sustainable use of renewable resources (Capitalize on use of renewables)

(6) Extend the durability of its products (Extend product durability)

(7) Increase the service intensity of its goods and services (Service intensity is increased).

This study will use these eco-design requirements as the criteria to determine whether a product has harmful impacts to the environment. If the answer is yes, then we will treat each of these impacts as a failure or problem as non-green phenomenon to be resolved in our proposed methodology. The idea involves using a list of seven requirements to allow designers or problem-solvers to check systematically to make sure that their products are environmentally friendly. Usually, these problems can be identified from consumers of the current products or the next generation products.

\subsection{Problem-Solving Process}

The method integrates AFD, contradiction matrix and eco-design elements to design green products. The idea is that when a product or system has a non-green problem, then it can be treated as a failure to be taken care. Once the failure is identified, the AFD method can be used. In addition, this study considers eco-design concepts in the product or system design process. In order to focus our proposal, the process will limit failures and issues related to the environmental impact of a product using the steps shown in Figure 2: (1) Failure analysis, (2) Determination of the cause, effect and non-green phenomena (NGP) of the failure, (3) Intensification of NGP and generate failure hypotheses from the results of the NGP Intensification, (4) Elimination of failures using contradiction matrix and (5) Assessment of alternative solutions. The process steps are explained in detail in the following. 


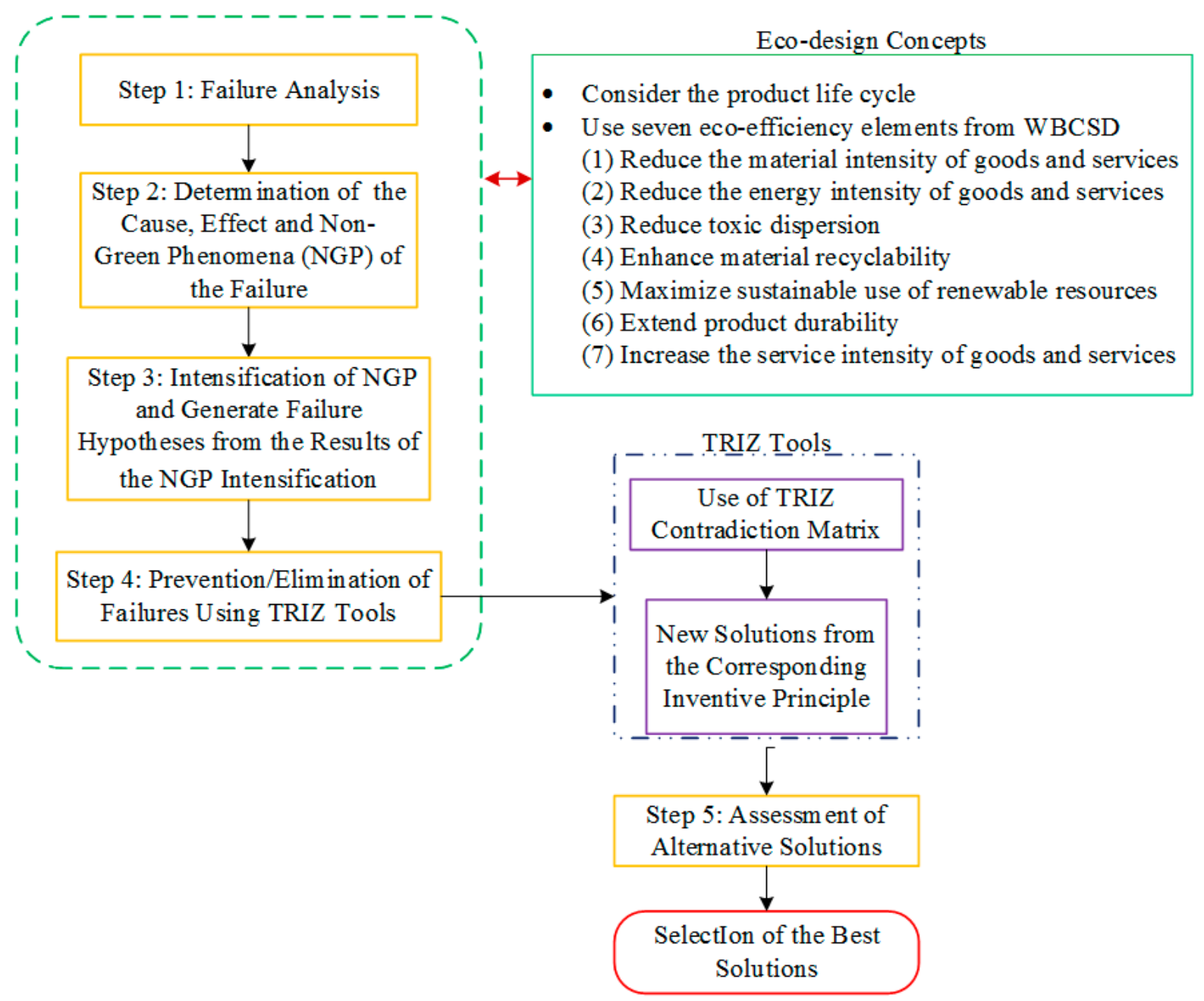

Figure 2. Proposed problem analysis and problem-solving process.

\section{Step 1: Failure Analysis}

The objective of the first step is to identify the failures being experienced by the product for different product life cycle stages, which include extraction and processing of raw materials, manufacturing, transportation/distribution, use/reuse/maintenance and disposal/waste recovery stages. In this part, failures/problems will be determined in the product failure analysis table. At the same time, product details like product name, product illustration, product components, primary useful function and useful functions will also be shown. The failures determined in this step will be used during the next step in determining the non-green phenomena of each failure.

Step 2: Determination of the Cause, Effect and Non-Green Phenomena (NGP) of the Failure

The second step is done through an analysis of failures to determine their causes and effects. Each failure will be analyzed separately and will have a different table. The non-green phenomena (NGP) of each problem will be determined by considering the seven eco-design elements of eco-efficiency to eliminate the different aspects of a product that may cause environmental impacts including: materials use, energy use, hazardous substances, recyclability, total product life and service intensity i.e., a non-green phenomenon. A NGP of a product failure is any phenomenon/function that violates the eco-design concepts given above in relation to the failure/problem, e.g., high energy consumption, toxic emission, service degradation, etc. The product failures/problems determined from the previous step will be analyzed considering the seven eco-design concepts to determine 
if they have non-green phenomena so that they can be eliminated. The NGP will be labeled as "NGP A1, NGP A2" depending on how many NGPs are determined for Failure A. According to DeSimone and Popoff [12], the greater the improvement in each of the seven eco-design elements, the more eco-efficient a product or process is.

Step 3: Intensification of NGP and Generate Failure Hypotheses from the Results of the NGP Intensification

This step focuses on intensifying the identified NGP. Based on the AFD concept of Kaplan et al. [30], the intensity of a harmful effect or undesired issues encountered is increased intentionally. Meanwhile, the NGP hypotheses are found by intensifying the NGP. In this step, the question of "how can the NGP be worsen" is asked to come up with the NGP hypotheses. The NGP hypotheses that are determined in this step will be used as a basis for the next step for prevention or elimination.

Step 4: Elimination of NGP Hypothesis with the Use of TRIZ Contradiction Matrix

In this step, the non-green hypothesis will be eliminated using the contradiction matrix with if-then-but rule. If the non-green hypothesis is eliminated, then the improving parameter is obtained, but the worsening parameter is also happened. From the contradiction, we can find the inventive principles suggested at their intersection in the Contradiction Matrix, as shown in Table 1 [24], which is defined by 40 inventive principles (Table 2) [24] and 39 engineering parameters (Table 3) [24]. These inventive principles will give solution triggers based on the knowledge of designers who solved similar problems before.

Table 1. Contradiction matrix [24].

\begin{tabular}{|c|c|c|c|c|c|}
\hline \multirow{2}{*}{\multicolumn{2}{|c|}{ Improving parameters }} & \multirow{2}{*}{$\begin{array}{c}1 \\
\begin{array}{c}\text { weight of moving } \\
\text { object }\end{array}\end{array}$} & \multirow{2}{*}{$\begin{array}{c}2 \\
\begin{array}{c}\text { weight of stationary } \\
\text { object }\end{array}\end{array}$} & \multirow{2}{*}{$\begin{array}{ll}\cdots \cdots \\
\cdots \cdots\end{array}$} & \multirow{2}{*}{$\frac{39}{\text { productivity }}$} \\
\hline & & & & & \\
\hline 1 & weight of moving object & & - & $\ldots \ldots$ & $35,3,24,37$ \\
\hline 2 & weight of stationary object & - & & $\ldots \ldots$ & $1,28,15,35$ \\
\hline$\vdots$ & : & $\vdots$ & : & & : \\
\hline : & $\vdots$ & $\vdots$ & $\vdots$ & & $\vdots$ \\
\hline 39 & productivity & $35,26,24,37$ & $28,27,15,3$ & $\ldots \ldots$ & \\
\hline
\end{tabular}

Table 2. 40 Inventive Principles [24].

\begin{tabular}{|l|l|l|l|l|l|}
\hline \multicolumn{9}{|c|}{ 40 Inventive Principles } \\
\hline 1 & Segmentation & 15 & Dynamics & 29 & Pneumatics and hydraulics \\
\hline 2 & Take-out & 16 & Partial or excessive action & 30 & Flexible shells and Thin films \\
\hline 3 & Local quality & 17 & Another dimension & 31 & Porous materials \\
\hline 4 & Asymmetry & 18 & Mechanical vibration & 32 & Colors changes \\
\hline 5 & Merging & 19 & Periodic action & 33 & Homogeneity \\
\hline 6 & Universality & 20 & Continuity of useful action & 34 & Discarding and recovering \\
\hline 7 & Nested Doll & 21 & Rushing through & 35 & Parameter changes \\
\hline 8 & Counterweight & 22 & Blessing in disguise & 36 & Phase transitions \\
\hline 9 & Preliminary anti-action & 23 & Feedback & 37 & Thermal expansion \\
\hline 10 & Prior action & 24 & Intermediary & 38 & Strong oxidants \\
\hline 11 & Cushion in advance & 25 & Self-service & 39 & Inert atmosphere \\
\hline 12 & Equipotentiality & 26 & Copying & 40 & Composite materials \\
\hline 13 & The other way around & 27 & Cheap, disposable objects & & \\
\cline { 1 - 2 } &
\end{tabular}


Table 3. 39 engineering parameters [24].

\begin{tabular}{|c|c|c|c|c|c|}
\hline \multicolumn{6}{|c|}{39 Engineering Parameters } \\
\hline 1 & weight of moving object & 14 & strength & 27 & reliability \\
\hline 2 & weight of stationary object & 15 & $\begin{array}{l}\text { duration of action by a moving } \\
\text { object }\end{array}$ & 28 & measurement accuracy \\
\hline 3 & length of moving object & 16 & $\begin{array}{l}\text { duration of action by a stationary } \\
\text { object }\end{array}$ & 29 & manufacturing precision \\
\hline 4 & length of stationary object & 17 & temperature & 30 & external harm affects the object \\
\hline 5 & area of moving object & 18 & illumination intensity & 31 & object-generated harmful factors \\
\hline 6 & area of stationary object & 19 & use of energy by moving object & 32 & ease of manufacture \\
\hline 7 & volume of moving object & 20 & use of energy by stationary object & 33 & ease of operation \\
\hline 8 & volume of stationary object & 21 & power & 34 & ease of repair \\
\hline 9 & speed & 22 & loss of energy & 35 & adaptability or versatility \\
\hline 10 & force & 23 & loss of substance & 36 & device complexity \\
\hline 11 & stress or pressure & 24 & loss of information & 37 & difficulty of detecting and measuring \\
\hline 12 & shape & 25 & loss of time & 38 & extent of automation \\
\hline 13 & stability of the object's composition & 26 & quantity of substance & 39 & productivity \\
\hline
\end{tabular}

\section{Step 5: Assessment of Alternative Solutions}

The possible alternative solutions will be evaluated using the five assessment criteria, which are product functionality, energy consumption, operation convenience, ease of manufacture and cost. For each criterion, three levels and their descriptions are written. Table 4 shows the scoring rubric.

Table 4. Scoring rubric for the criteria.

\begin{tabular}{ccc}
\hline Criteria & 1-Poor & 3-Average \\
\hline Product functionality & Poor functionality & Average functionality \\
Energy consumption & High energy consumption & Average energy consumption \\
Operation convenience & Difficult to operate. & Can tolerate the complexity of operation. \\
Ease of manufacture & Difficult to manufacture. & Can tolerate the complexity of manufacture. \\
Cost & High cost & Reasonable cost \\
\hline
\end{tabular}

In Table 4, the solution scales of one (1), three (3) and nine (9) represent the performance of poor, average and excellent accordingly. The alternative solutions will be assessed corresponding to different criteria. The design of the new product will be based on the results of the assessment of the alternative solutions. However, after assessment there might be a need for the alternative solutions to be selected or combined, and it depends on the problem solvers' decision on which kind of solutions they want to implement. The problem solver will also decide the minimum total score of the alternative solutions he/she wants to use in creating the new product.

\section{Case Study}

A washing machine will be used to demonstrate the proposed methodology with five steps discussed in Section 3. The reason for selecting washing machine as a case study is because washing machine is very rich to be identified non-green phenomena [15].

\section{Step 1: Failure Analysis}

In this step, product details like product name, product illustration, product components, primary useful function, useful functions and failures/problems are listed in Table 5 together with the identified product failures, as shown in the following:

A. Washing machine vibrates during the spin cycle.

B. Excessive wrinkling of clothes because of not removing the clothes right away after washing.

C. Too much detergent is used.

For demonstration purpose, here we only focus on the use stage of the product to improve eco-performance. As to other stages, they can be considered similarly. 
Table 5. Product failure analysis.

\begin{tabular}{ll}
\hline Product Name & Product Illustration
\end{tabular}

Top load washing machine

Product components

Tub (interior), Timer control, Water level control, Wash speed selector, Water supply hoses, Door (top cover), Drain hose, Water inlet valves, Water filter, Spin Pulley, Spin Assembly, Water pump, Water hose, Transmission, Motor, Agitator, Plug

\section{Primary useful function}

Washes clothes
Useful function
Removes stains
Removes bad odor
Failure/Problem
A. Washing machine vibrates during the spin cycle.
B. Excessive wrinkling of clothes because of not removing the clothes right away after the wash.
C. Too much detergent is used.

C. Too much detergent is used.

Step 2: Determination of the Cause, Effect and Non-Green Phenomena (NGP) of the Failure

The second step is done through analysis of failures to determine its cause and effects. Each failure will be analyzed separately. The non-green phenomena (NGP) of each failure/problem will be determined by considering the seven eco-design concepts. The three product failures stated in Table 5 will be analyzed in this step. Each failure/problem will be observed considering the seven eco-design requirements or eco-efficiency elements to determine the non-green phenomenon.

a. How to generate NGP with the first failure/problem (A) which is "washing machine makes vibration during the spin cycle"?

As shown in Table 6, the cause of the failure is washer, not level, which results in making the washing machine out of balance and vibrating during use. This leads to one NGP, which is:

NGP A1: Parts have become worn out or loose.

As shown, the NGP is labeled as NGP A1 because it is from failure A. However, if there are two failures, then it will be labeled as NGP A1 and NGP A2. It depends on how many NGPs are determined. This will also be done on failure $B$, and the same with failure C. After Table 6, if there is no NGP corresponding to the eco-design requirements, then the empty space will be skipped for simplicity. 
Table 6. Product failure analysis questionnaire for the failure/problem A.

\begin{tabular}{|c|c|}
\hline \multicolumn{2}{|c|}{ Failure/Problem } \\
\hline \multicolumn{2}{|c|}{$\begin{array}{l}\text { Cause of the failure/problem } \\
\text { Effect of the failure/problem }\end{array}$} \\
\hline & Eco-design requirements: \\
\hline 1. & Reduce the material intensity of its goods and services \\
\hline 2. & Reduce the energy intensity of its goods and services \\
\hline 3. & Reduce the dispersion of any toxic materials \\
\hline 4. & Enhance the recyclability of its materials \\
\hline 5. & Maximize the sustainable use of renewable resources \\
\hline 6. & Extend the durability of its products \\
\hline 7. & Increase the service intensity of its goods and services \\
\hline
\end{tabular}

b. How to generate NGP with the second failure/problem (B) which is "excessive wrinkling of clothes because of not removing the clothes right away after the wash".

As shown in Table 7, excessive wrinkling of clothes because of not removing the clothes right away after the wash leads to two NGPs, which are:

NGP B1: Clothes should be rewashed to remove wrinkles, which will increase water consumption.

NGP B2: Clothes should be ironed in order to wear it immediately, which will increase energy consumption.

Table 7. Product failure analysis questionnaire for problem B.

\begin{tabular}{|c|c|}
\hline Failure/Problem & $\begin{array}{l}\text { B. Excessive wrinkling of clothes because of not removing the } \\
\text { clothes right away after the wash. }\end{array}$ \\
\hline Cause of the failure/problem & $\begin{array}{l}\text { Accidentally forgets to remove the clothes from the washer right } \\
\text { away when the wash is done. }\end{array}$ \\
\hline Effect of the failure/problem & Clothes can't be used immediately after drying. \\
\hline Reduce the energy intensity of its goods and services & $\begin{array}{l}\text { NGP: } \\
\text { B1: Clothes should be rewashed to remove wrinkles, which will } \\
\text { increase water consumption. } \\
\text { B2: Clothes should be ironed in order to wear it immediately, } \\
\text { which will increase energy consumption. }\end{array}$ \\
\hline
\end{tabular}

c. How to generate NGP with the third failure/problem (C) which is "too much detergent is used"?

As shown in Table 8, the third failure/problem (C) which is "too much detergent is used" leads to one NGP:

NGP C1: Clothes will not be properly rinsed.

Table 8. Product failure analysis questionnaire for problem C.

\begin{tabular}{|c|c|}
\hline Failure/Problem & C. Too much detergent is used. \\
\hline Cause of the failure/problem & $\begin{array}{l}\text { No measuring tools. } \\
\text { The user is just a beginner }\end{array}$ \\
\hline Effect of the failure/problem & Suds will be left on the clothes. \\
\hline $\begin{array}{l}\text { Eco-design requirements: } \\
\text { 7. Increase the service intensity of its goods and services }\end{array}$ & $\begin{array}{l}\text { NGP: } \\
\text { C1. Clothes will not be properly rinsed. }\end{array}$ \\
\hline
\end{tabular}


After converting from problems or failures, all the NGPs are summarized in Table 9.

Table 9. Summary of the identified NGPs.

\begin{tabular}{ll}
\hline Failure/Problem & Non-Green Phenomenon \\
\hline A. Washing machine vibrates during the spin cycle. & NGP A1: Parts have become worn out or loose. \\
$\begin{array}{l}\text { B. Excessive wrinkling of clothes because of not removing the } \\
\text { clothes right away after the wash. }\end{array}$ & $\begin{array}{l}\text { NGP B1: Clothes should be rewashed to remove wrinkles, } \\
\text { which will increase water consumption. }\end{array}$ \\
& $\begin{array}{l}\text { NGP B2: Clothes should be ironed in order to wear them } \\
\text { immediately, which will increase energy consumption. }\end{array}$ \\
C. Too much detergent is used. & NGP C1: Clothes will not be properly rinsed. \\
\hline
\end{tabular}

Step 3: Intensification of NGP and Generation of Failure Hypotheses from the Results of the NGP Intensification

This part focuses on intensifying the identified NGP. In this step the question "how can the NGP be worsened?" is asked to come up with the NGP hypotheses as shown in Table 10. For example, for NGP A1: parts have become worn out or loose, its intensification will be "parts will completely loosen" (Hypothesis 1, H1), then we will have the result of "the whole washing machine will be broken". For NGP B1: clothes should be rewashed to remove wrinkles, which will increase water consumption. If lower water temperature is used (H2) [48] and faster spin speed is used (H3), then wrinkles get even worse.

Table 10. Intensification of non-green phenomenon.

\begin{tabular}{|c|c|c|c|c|}
\hline Failure/Problem & Non-Green Phenomenon & $\begin{array}{l}\text { Item That Relates to the } \\
\text { NGP }\end{array}$ & $\begin{array}{c}\text { How to Make the NGP Even } \\
\text { Worse? } \\
\text { (NGP Hypothesis) }\end{array}$ & Result \\
\hline $\begin{array}{l}\text { A. Washing machine vibrates } \\
\text { during the spin cycle. }\end{array}$ & $\begin{array}{l}\text { NGP A1: Parts have become } \\
\text { worn out or loose. }\end{array}$ & Vibration & $\begin{array}{l}\text { Parts will completely loosen. } \\
\text { (H1) }\end{array}$ & $\begin{array}{l}\text { Whole washing machine will } \\
\text { be broken. }\end{array}$ \\
\hline \multirow{3}{*}{$\begin{array}{l}\text { B. Excessive wrinkling of } \\
\text { clothes because of not } \\
\text { removing the clothes right } \\
\text { away after the wash. }\end{array}$} & \multirow{2}{*}{$\begin{array}{l}\text { NGP B1: Clothes should be } \\
\text { rewashed to remove wrinkles, } \\
\text { which will increase water } \\
\text { consumption. }\end{array}$} & \multirow[t]{2}{*}{ Water } & Used colder water. (H2) & \multirow{2}{*}{$\begin{array}{l}\text { Wrinkles get worse. } \\
\text { Wrinkles get worse \& use } \\
\text { more electricity. }\end{array}$} \\
\hline & & & Used faster spin speed. (H3) & \\
\hline & $\begin{array}{l}\text { NGP B2: Clothes should be } \\
\text { ironed in order to wear them } \\
\text { immediately, which will } \\
\text { increase energy consumption. }\end{array}$ & Electricity & $\begin{array}{l}\text { Takes longer ironing time } \\
\text { because of excessive wrinkles. } \\
\text { (H4) }\end{array}$ & $\begin{array}{l}\text { Clothes will be damaged. } \\
\text { Uses more electricity. }\end{array}$ \\
\hline $\begin{array}{l}\text { C. Too much detergent is } \\
\text { used. }\end{array}$ & $\begin{array}{l}\text { NGP C1: Clothes will not be } \\
\text { properly rinsed. }\end{array}$ & Clothes & $\begin{array}{l}\text { Accidentally put in the whole } \\
\text { detergent. (H5) }\end{array}$ & $\begin{array}{l}\text { Bubbles will overflow. } \\
\text { Clothes will be damaged } \\
\text { because more water will be } \\
\text { used to rinse. }\end{array}$ \\
\hline
\end{tabular}

Step 4: Prevention/Elimination of NGP Hypothesis with the Use of TRIZ Tools

In this step, the non-green hypothesis happened in Step 3 will be eliminated using the contradiction matrix. The improving and worsening parameters will be used to find the inventive principles suggested from the contradiction matrix as shown in Table 11. For example, if we want to prevent Hypothesis 1: "prevent the parts from loosening", then we have to make parts tight, which will improve the product strength (parameter 14); however, this is difficult to accomplish, which will worsen parameter 32 (ease of manufacture). From the contradiction matrix, we can find inventions 11 (Beforehand cushioning), 3 (Local quality), 10 (Preliminary action) and 32 (Color changes). These inventive principles can serve as solution triggers for the hypothesis developed from the intensification of the failure or problem. 
Table 11. Inventive principles for each hypothesis.

\begin{tabular}{|c|c|c|c|c|c|}
\hline Hyp. & Item & $\begin{array}{c}\text { If } \\
\text { (Prevention or } \\
\text { Elimination of } \\
\text { Non-Green Hypothe- } \\
\text { sis/Assumption) }\end{array}$ & $\begin{array}{c}\text { Then } \\
\text { (Improving Parameters) }\end{array}$ & $\begin{array}{c}\text { But } \\
\text { (Worsening } \\
\text { Parameters) }\end{array}$ & Inventive Principles \\
\hline H1 & Vibration & $\begin{array}{l}\text { Prevent the parts from } \\
\text { loosening. }\end{array}$ & $\begin{array}{l}\text { Make parts tight. } \\
\text { (14. Strength) }\end{array}$ & $\begin{array}{l}\text { Difficult to accomplish. } \\
\text { (32. Ease of } \\
\text { manufacture) }\end{array}$ & $\begin{array}{l}\text { 11. Beforehand cushioning } \\
\text { 3. Local quality } \\
\text { 10. Preliminary action } \\
\text { 32. Color changes }\end{array}$ \\
\hline $\mathrm{H} 2$ & Water & $\begin{array}{l}\text { Prevent wrinkles from } \\
\text { getting worse by using } \\
\text { warm water. }\end{array}$ & $\begin{array}{l}\text { Reduce wrinkles. } \\
\text { (39. Productivity) }\end{array}$ & $\begin{array}{l}\text { Increase electricity } \\
\text { consumption. ( } 22 \text {. Loss } \\
\text { of energy) }\end{array}$ & $\begin{array}{l}\text { 28. Replace a mechanical } \\
\text { system } \\
\text { 10. Preliminary action } \\
\text { 29. Pneumatics or hydraulics } \\
\text { 35. Physical or chemical } \\
\text { properties }\end{array}$ \\
\hline $\mathrm{H} 3$ & Electricity & $\begin{array}{l}\text { Prevent wrinkles from } \\
\text { getting worse by using } \\
\text { slower spin. }\end{array}$ & $\begin{array}{l}\text { Reduce electricity consumption } \\
\text { (22. Loss of energy) }\end{array}$ & $\begin{array}{l}\text { Does not dry the } \\
\text { clothes properly. } \\
\text { (39. Productivity) }\end{array}$ & $\begin{array}{l}\text { 28. Replace a mechanical } \\
\text { system } \\
\text { 10. Preliminary action } \\
\text { 29. Pneumatics or hydraulics } \\
\text { 35. Physical or chemical } \\
\text { properties }\end{array}$ \\
\hline $\mathrm{H} 4$ & Clothes & $\begin{array}{l}\text { Eliminate wrinkles by } \\
\text { using a powerful iron. }\end{array}$ & $\begin{array}{l}\text { Less time to remove wrinkles. } \\
\text { (27. Reliability) }\end{array}$ & $\begin{array}{l}\text { Expensive. } \\
\text { (38. Extent of } \\
\text { automation) }\end{array}$ & $\begin{array}{l}\text { 11. Beforehand cushioning } \\
\text { 13. 'The other way around' } \\
\text { 27. Cheap short-living objects }\end{array}$ \\
\hline H5 & Clothes & $\begin{array}{l}\text { Avoid putting in the } \\
\text { whole detergent. }\end{array}$ & $\begin{array}{l}\text { Makes the clothes last } \\
\text { longer. } \\
\text { Prevents the machine } \\
\text { from being broken due to } \\
\text { overflowing of bubbles. } \\
\text { - } \quad \text { Conserves water. } \\
\text { - }(27 . \text { Reliability) }\end{array}$ & $\begin{array}{l}\text { Need to install } \\
\text { additional functions } \\
\text { (36. Device complexity) }\end{array}$ & $\begin{array}{l}\text { 13. 'The other way around' } \\
\text { 35. Parameter changes } \\
\text { 1. Segmentation }\end{array}$ \\
\hline
\end{tabular}

In Table 11, the inventive principles for solving the failure/problem are determined. These will be used in Table 12 to find feasible solutions to the NGP of the problems. There are two solutions found for Hypothesis H1, H4, and H5, and one solution found for Hypothesis $\mathrm{H} 2$ and H3. In total, there are eight solutions found. The purpose of this study is to demonstrate how the product innovative process works, so the betterness of the solution is not our main concern, which will leave the product developer to make efforts.

Table 12. Possible solutions for the NGP hypothesis.

\begin{tabular}{|c|c|c|c|}
\hline Hyp. & NGP Hypothesis & Inventive Principles & Possible Solutions \\
\hline \multirow{4}{*}{ H1 } & \multirow{4}{*}{ Parts will completely loosen. } & 11. Beforehand cushioning & $\begin{array}{l}\text { Add built-in vibration reduction } \\
\text { technology. (Solution No. 1-1) }\end{array}$ \\
\hline & & 3. Local quality & None \\
\hline & & 10. Preliminary action & Install an anti-vibration pad under the \\
\hline & & 32. Color changes & $\begin{array}{l}\text { washing machine. (Solution No. 1-2) } \\
\text { None }\end{array}$ \\
\hline \multirow{4}{*}{$\mathrm{H} 2$} & \multirow{4}{*}{ Used higher water temperature. } & 28. Replace a mechanical system & None \\
\hline & & 10. Preliminary action & $\begin{array}{l}\text { Install temperature sensors that can } \\
\text { automatically control the water } \\
\text { temperature to provide optimum washing } \\
\text { performance. } \\
\text { (Solution No. 2-1) }\end{array}$ \\
\hline & & 29. Pneumatics or hydraulics & None \\
\hline & & 35. Physical or chemical properties & None \\
\hline
\end{tabular}


Table 12. Cont.

\begin{tabular}{|c|c|c|c|}
\hline Hyp. & NGP Hypothesis & Inventive Principles & Possible Solutions \\
\hline \multirow{4}{*}{$\mathrm{H} 3$} & \multirow{4}{*}{ Used faster spin speed. } & 28. Replace a mechanical system & None \\
\hline & & 10. Preliminary action & $\begin{array}{l}\text { Various spin speed and wash motions } \\
\text { customized for different types of fabric. } \\
\text { (Solution No. 3-1) }\end{array}$ \\
\hline & & 29. Pneumatics or hydraulics & None \\
\hline & & 35. Physical or chemical properties & None \\
\hline \multirow{3}{*}{$\mathrm{H} 4$} & \multirow{3}{*}{$\begin{array}{l}\text { Takes longer ironing time } \\
\text { because of excessive wrinkles. }\end{array}$} & 11. Beforehand cushioning & None \\
\hline & & 13. The other way round & $\begin{array}{l}\text { Can get connected to the phone via Wi-Fi } \\
\text { to get alerts when the wash is done. } \\
\text { (Solution No. 4-1) }\end{array}$ \\
\hline & & 27. Cheap short-living objects & $\begin{array}{l}\text { Add an alarm that alerts the user when the } \\
\text { wash is done. (Solution No. 4-2) }\end{array}$ \\
\hline \multirow{3}{*}{$\mathrm{H} 5$} & \multirow{3}{*}{$\begin{array}{l}\text { Accidentally put in the whole } \\
\text { detergent. }\end{array}$} & 13. The other way round & $\begin{array}{l}\text { A detergent/fabric conditioner dispenser } \\
\text { that can sense the load size to determine } \\
\text { the amount of detergent to release. } \\
\text { (Solution No. 5-1) }\end{array}$ \\
\hline & & 35. Parameter changes & None \\
\hline & & 1. Segmentation & $\begin{array}{l}\text { Add detergent tray that distributes } \\
\text { detergent/fabric conditioner. } \\
\text { (Solution No. 5-2) }\end{array}$ \\
\hline
\end{tabular}

Table 13 illustrates and summarizes the solutions shown in Table 12 so that it will be easy to evaluate them.

Table 13. Summarized solutions per NGP hypothesis.

\begin{tabular}{|c|c|c|c|}
\hline Hyp. & Solution Number & Solution & Solution Illustration \\
\hline \multirow[b]{2}{*}{$\mathrm{H} 1$} & No. $1-1$ & $\begin{array}{l}\text { Add built-in vibration reduction } \\
\text { technology. }\end{array}$ & $\begin{array}{l}\text { Add a technology such as VRT Plus } \\
\text { technology [49]. } \\
\text { Install anti-vibration pads [50]. }\end{array}$ \\
\hline & No. $1-2$ & $\begin{array}{l}\text { Install an anti-vibration pad under the } \\
\text { washing machine. }\end{array}$ & \\
\hline $\mathrm{H} 2$ & No. 2-1 & $\begin{array}{l}\text { Temperature sensors that can } \\
\text { automatically control the water } \\
\text { temperature to provide optimum } \\
\text { washing performance. }\end{array}$ & $\begin{array}{l}\text { The sensors can have the following setting } \\
\text { for different wash modes [51]: } \\
\text { Cold } 60^{\circ} \mathrm{F}-80^{\circ} \mathrm{F} \\
\text { Warm } 80^{\circ} \mathrm{F}-100^{\circ} \mathrm{F} \\
\text { Hot } 110^{\circ} \mathrm{F}-140^{\circ} \mathrm{F} \text {. }\end{array}$ \\
\hline $\mathrm{H} 3$ & No. 3-1 & $\begin{array}{l}\text { Various spin speed and wash motions } \\
\text { customized for different types of fabric. }\end{array}$ & See the reference [52]. \\
\hline \multirow{3}{*}{$\mathrm{H} 4$} & & & Remote control using an app [53]. \\
\hline & No. 4-1 & $\begin{array}{l}\text { Can get connected to the phone via Wi-Fi } \\
\text { to get alerts when the wash is done. }\end{array}$ & \\
\hline & No. 4-2 & $\begin{array}{l}\text { Add an alarm that alerts the user when } \\
\text { the wash is done. }\end{array}$ & \\
\hline
\end{tabular}


Table 13. Cont.

\begin{tabular}{|c|c|c|c|}
\hline Hyp. & Solution Number & Solution & Solution Illustration \\
\hline \multirow{4}{*}{ H5 } & & & $\begin{array}{l}\text { Use a technology such as SmartDispense } \\
\text { technology to automatically dispense } \\
\text { detergent and fabric softener [54]. }\end{array}$ \\
\hline & No. $5-1$ & $\begin{array}{l}\text { A detergent/fabric conditioner dispenser } \\
\text { that can sense the load size to determine } \\
\text { the amount of detergent to release. }\end{array}$ & \\
\hline & & & \\
\hline & No. 5-2 & $\begin{array}{l}\text { Add detergent tray that distributes } \\
\text { detergent/fabric conditioner. }\end{array}$ & \\
\hline
\end{tabular}

Step 5: Assessment of Alternative Solutions

After finding possible alternative solutions, these will be evaluated using the five assessment criteria which are: product functionality, energy consumption, operation convenience, ease of manufacture and cost. The alternative solutions are assessed in Table 14. Each solution will be scored according to the different criteria.

Table 14. Assessment of alternative solutions.

\begin{tabular}{|c|c|c|c|c|c|c|c|}
\hline \multirow{2}{*}{\multicolumn{2}{|c|}{ Solution Number }} & \multicolumn{6}{|c|}{ Criteria } \\
\hline & & \multirow{2}{*}{$\begin{array}{c}\begin{array}{c}\text { Product } \\
\text { Functionality }\end{array} \\
9\end{array}$} & \multirow{2}{*}{$\begin{array}{c}\text { Energy Con- } \\
\text { sumption }\end{array}$} & \multirow{2}{*}{$\begin{array}{c}\begin{array}{c}\text { Operation } \\
\text { Convenience }\end{array} \\
9\end{array}$} & \multirow{2}{*}{$\begin{array}{c}\begin{array}{c}\text { Ease of } \\
\text { Manufacture }\end{array} \\
1\end{array}$} & \multirow{2}{*}{$\frac{\text { Cost }}{1}$} & \multirow{2}{*}{$\begin{array}{c}\text { Total Score } \\
29\end{array}$} \\
\hline & No. $1-1$ & & & & & & \\
\hline $\mathrm{H} 1$ & No. 1-2 & 9 & 9 & 9 & 3 & 1 & 31 \\
\hline $\mathrm{H} 2$ & No. 2-1 & 9 & 3 & 9 & 3 & 3 & 27 \\
\hline H3 & No. 3-1 & 9 & 9 & 9 & 3 & 3 & 33 \\
\hline \multirow{2}{*}{$\mathrm{H} 4$} & No. $4-1$ & 9 & 9 & 9 & 1 & 3 & 31 \\
\hline & No. $4-2$ & 9 & 9 & 9 & 3 & 3 & 33 \\
\hline \multirow{2}{*}{ H5 } & No. 5-1 & 9 & 9 & 9 & 1 & 3 & 31 \\
\hline & No. 5-2 & 9 & 9 & 9 & 3 & 3 & 33 \\
\hline
\end{tabular}

The design of the new product will be based from the results of the assessment of alternative solutions. Some solutions, such as No.5-1 and No. 5-2 are needed to choose one, but some solutions can be selected based on the developer's decision or customer's need. The product developer will also decide the minimum total score of the alternative solutions he/she wants to use in creating the new product.

\section{Conclusions}

This study examines the integration of AFD, environmental considerations and TRIZ tools to solve product failures to reduce the environmental impacts of product failure. A new green product design process with anticipatory non-green-phenomena determination was developed. The product failures were analyzed first to find non-green phenomenon. Then the NGP were intensified by thinking about how to make NGP worse to find the NGP hypotheses. Lastly, the contradiction matrix and inventive principles were used to eliminate the NGP hypotheses to improve the product eco-efficiency and discover 
green design solutions. The washing machine was the product used to demonstrate the methodology and many eco-design solutions were derived for the washing machine product design. We believe that our methodology can serve as a reference to product designers to provide a systematic way of designing green products for their product life cycle (although only the use stage is demonstrated in our case study due to space limitation) and help designers in integration of AFD in green product design.

This study only concerns the green aspects in the product design process. In practice, it needs to incorporate other aspects, such as product function, cost and manufacturing, which will make more complete considerations. In recent years, circular economics [56-58] is also a new area to be considered when we are designing products.

Author Contributions: All authors designed the research and wrote the manuscript. M.D.M.L. and P.-H.C. collected and analyzed the data. H.R. controlled the quality assurance. All authors have read and agreed to the published version of the manuscript.

Funding: This research was funded by the Ministry of Science and Technology of the Republic of China, grant numbers MOST 107-2221-E-033-054-MY3 and MOST 109-2221-E-033-035 and The APC was funded by the grant of MOST 107-2221-E-033-054-MY3 and CYCU.

Acknowledgments: This work was supported in part by the Ministry of Science and Technology of the Republic of China under grants MOST 107-2221-E-033-054-MY3 and MOST 109-2221-E-033-035.

Conflicts of Interest: The authors declare no conflict of interest.

\section{References}

1. Appolloni, A.; Sun, H.; Jia, F.; Li, X. Green procurement in the private sector: A state of the art review between 1996 and $2013 . J$. Clean. Prod. 2014, 85, 122-133. [CrossRef]

2. Cheng, W.; Appolloni, A.; D'Amato, A.; Zhu, Q. Green public procurement, missing concepts and future trends-A critical review. J. Clean. Prod. 2018, 176, 770-784. [CrossRef]

3. Qu, Y.; Yu, Y.; Appolloni, A.; Li, M.; Liu, Y. Measuring green growth efficiency for Chinese manufacturing industries. Sustainability 2017, 9, 637. [CrossRef]

4. Testa, F.; Nucci, B.; Iraldo, F.; Appolloni, A.; Daddi, T. Removing obstacles to the implementation of LCA among SMEs: A collective strategy for the valorization of recycled Cardato. J. Clean. Prod. 2017, 156, 923-931. [CrossRef]

5. Rizzi, F.; Frey, M.; Testa, F.; Appolloni, A. Environmental value chain in green SME networks: The threat of the Abilene paradox. J. Clean. Prod. 2014, 85, 265-275. [CrossRef]

6. Hozik, M. Making the Green by Going Green: Increased Demand for Green Products and the FTC's Role in a Greener Future. 2016. Available online: https://gelr.org/2016/02/01/making-the-green-by-going-green-increased-demand-for-green-productsand-the-ftcs-role-in-a-greener-future-georgetown-environmental-law-review / (accessed on 24 May 2020).

7. Curtin, M. 73 Percent of Millennials Are Willing to Spend More Money on This 1 Type of Product. It's not even close to avocado toast. Column, Inc.com, 30 March 2018. Available online: https:/ / www.inc.com/melanie-curtin/73-percent-of-millennials-arewilling-to-spend-more-money-on-this-1-type-of-product.html (accessed on 24 May 2020).

8. Mzxwell, D.; van der Vorst, R. Developing sustainable products and services. J. Clean. Prod. 2003, 11, 883-895. [CrossRef]

9. Vieura, J. What Makes a Product Sustainable? 2019. Available online: https://www.linkedin.com/pulse/what-makes-productsustainable-joana-vieira (accessed on 22 December 2020).

10. Yanarella, E.J.; Levine, R.S.; Robert, W.; Lancaster, R.W. Research and solutions: Green vs. sustainability: From semantics to enlightenment. Sustainability 2009, 2, 296-302. [CrossRef]

11. Jezerc, G. First Insight Finds Expectations for Sustainable Retail Practices Growing with the Rise of Gen Z Shoppers. Businesswire. 14 January 2020. Available online: https:/ / www.businesswire.com/news/home/20200114005180/en/insight-finds-expectationssustainable-retail-practices-growing (accessed on 24 May 2020).

12. DeSimone, L.; Popoff, F. Eco-Efficiency: The Business Link to Sustainable Development; The MIT Press: Cambridge, MA, USA, 2000.

13. WBCSD. Eco-Efficiency: Creating More Value with Less Impact. 2000. Available online: https://arquivo.pt/wayback/20160515 140905/http:/ / www.wbcsd.org/web/publications/eco_efficiency_creating_more_value.pdf (accessed on 24 May 2020).

14. Kobayashi, H. A systematic approach to eco-innovative product design based on life cycle planning. Adv. Eng. Inform. 2006, 20, 113-125. [CrossRef]

15. European Commision. Washing Machines, Energy Labelling and Ecodesign Requirements Apply to This Product. Available online: https:/ / ec.europa.eu/info/energy-climate-change-environment/standards-tools-and-labels/products-labelling-rulesand-requirements/energy-label-and-ecodesign/energy-efficient-products/washing-machines_en (accessed on 27 December 2020). 
16. BIO Intelligence Service. Material-Efficiency Ecodesign Report and Module to the Methodology for the Ecodesign of Energy-Related Products (MEErP), Part 1 \& 2-Enhancing MEErP for Ecodesign; Prepared for: European Commission-DG Enterprise and Industry; The Publications Office of the European Union: Luxembourg, 2013.

17. Eltayeba, T.K.; Zailani, S.; Ramayah, T. Green supply chain initiatives among certified companies in Malaysia and environmental sustainability: Investigating the outcomes. Resour. Conserv. Recycl. 2011, 55, 495-506. [CrossRef]

18. Da Luz, L.M.; de Francisco, A.C.; Piekarski, C.M.; Salvador, R. Integrating life cycle assessment in the product development process: A methodological approach. J. Clean. Prod. 2018, 193, 28-42. [CrossRef]

19. Shetty, D. Product Design for Engineers; Cengage Learning: Boston, MA, USA, 2015.

20. Ideation International Inc. AFD. Available online: http://www.whereinnovationbegins.net/ (accessed on 4 May 2020).

21. Proseanic, V.; Tananko, D.; Visnepolschi, S. The experience of the anticipatory failure determination (AFD) method applied to an engine concern. In Proceedings of the TRIZCON 2000, Nashua, NH, USA, 30 April-2 May 2000.

22. Sunday, E. Extension and Modification of Anticipatory Failure Determination Approach Based on I-TRIZ. Master's Thesis, University of Stavanger, Stavanger, Norway, 2014.

23. Wang, L.X.; Qiu, W.G. E-bike head-lamp failure analysis based-on failure anticipation analysis. Appl. Mech. Mater. 2014, 668-669, 916-919. [CrossRef]

24. Altshuller, G. The Innovation Algorithm: TRIZ, Systematic Innovation and Technical Creativity; Technical Innovation Center Inc.: Worcester, UK, 1999.

25. The TRIZ Journal. What is TRIZ. Available online: https://triz-journal.com/triz-what-is-triz/ (accessed on 4 May 2020).

26. Thurnes, C.M.; Zeihsel, F.; Visnepolschi, S.; Frank Hallfell, F. Using TRIZ to invent failures-Concept and application to go beyond traditional FMEA. Procedia Eng. 2015, 131, 426-450. [CrossRef]

27. Altshuller, G.; Zlotin, B.; Zusman, A.; Filatov, V. Searching for New Ideas; Kartya Moldovenyaska Publishing House: Kishniev, Moldova, 1989.

28. Zlotin, B.; Zusman, A. Solving All Scientific Problems; Kartya Moldovenyaska Publishing House: Kishniev, Moldova, 1989.

29. Kaplan, S. Finding failures before they find us: An introduction to the theory of scenario structuring and the method of anticipatory failure determination. In Proceedings of the 9th Symposium on Quality Function Deployment, Novi, MI, USA, 15-16 June 1997; Available online: http: / / www.qfdi.org (accessed on 24 May 2020).

30. Ungvari, S. The anticipatory failure determination fact sheet. TRIZ J. 1999. Available online: https://triz-journal.com/ anticipatory-failure-determination-fact-sheet/ (accessed on 24 May 2020).

31. Kaplan, S.; Zlotin, B.; Visepolschi, S.; Zusman, A. New Tools for Failure and Risk Analysis: An Introduction to Anticipatory Failure Determination (AFD) and the Theory of Scenario Structuring; Ideation International Incorporated: Farmington Hills, MI, USA, 1999.

32. Chybowski, L.; Gawdzińska, K.; Souchkov, V. Applying the anticipatory failure determination at a very early stage of a system's development: Overviewand case study. Multidiscip. Asp. Prod. Eng. 2018, 1, 205-215. [CrossRef]

33. McLennan, J.F. The Philosophy of Sustainable Design; Ecotone Publishing: Seattle, WA, USA, 2004.

34. Andrae, A.S.G.; Xia, M.; Zhang, J.; Tang, X. Practical Eco-Design and Eco-Innovation of Consumer Electronics-The Case of Mobile Phones. Challenges 2016, 7, 3. [CrossRef]

35. Ferrendier, S.; Mathieux, F.; Rebitzer, G.; Simon, M.; Froelich, D. Eco-design Guide: Environmentally Improved Product Design Case Studies of the European Electrical and Electronics Industry. ECOLIFE Themat. Netw. 2002. [CrossRef]

36. Clark, G.; Kosoris, J.; Hong, L.N.; Crul, M. Design for Sustainability: Current Trends in Sustainable Product Design and Development. Sustainability 2009, 1, 409-424. [CrossRef]

37. Chou, J.-R. An ARIZ-based life cycle engineering model for eco-design. J. Clean. Prod. 2014, 66, 210-223. [CrossRef]

38. Eksi, G.; Karaosmanoglu, F. Life cycle assessment of combined bioheat and biopower production: An eco-design approach. J. Clean. Prod. 2018, 197, 264-279. [CrossRef]

39. Foulet, A.; Bouchez, T.; Quemener, E.D.-L.; Giard, L.; Renvoise, L.; Aissani, L. Eco-design of microbial electrochemical technologies for the production of waste-based succinic acid thanks to a life cycle assessment. J. Clean. Prod. 2019, 225, 1155-1168. [CrossRef]

40. Foschi, E.; Zanni, S.; Bonoli, A. Combining eco-design and lca as decision-making process to prevent plastics in packaging application. Sustainability 2020, 12, 9738. [CrossRef]

41. Chen, S.; Qiu, H.; Xiao, H.; He, W.; Mou, J.; Siponen, M. Consumption behavior of eco-friendly products and applications of ICT innovation. J. Clean. Prod. 2021, 287, 125436. [CrossRef]

42. Choi, I.; Kim, J.H.; Kim, D.W. LCA-based investigation of environmental impacts for novel double-beam floor system subjected to high gravity loads. Sustainability 2020, 12, 9193. [CrossRef]

43. Han, H.; Quan, W.; Lho, L.H.; Yu, J. Eco-design of airport buildings and customer responses and behaviors: Uncovering the role of biospheric value, reputation, and subjective well-being. Sustainability 2020, 12, 10059. [CrossRef]

44. Knapp, S.; Schmauck, S.; Zehnsdorf, A. Biodiversity impact of green roofs and constructed wetlands as progressive ecotechnologies in urban areas. Sustainability 2019, 11, 5846. [CrossRef]

45. De Oliveira Neto, G.C.; Chaves, L.E.C.; Pinto, L.F.R.; Santana, J.C.C.; Amorim, M.P.C.; Rodrigues, M.J.F. Economic, environmental and social benefits of adoption of pyrolysis process of tires: A feasible and ecofriendly mode to reduce the impacts of scrap tires in Brazil. Sustainability 2019, 11, 2076. [CrossRef]

46. Kibert, C.J. Sustainable Construction: Green Building Design and Delivery; Wiley: Hoboken, NJ, USA, 2012.

47. WBCSD. Eco-Efficiency Learning Module; WBCSD: Geneva, Switzerland, 2006. 
48. WikiHow Website. How to Reduce Laundry Wrinkles. Available online: https://www.wikihow.com/Reduce-Laundry-Wrinkles (accessed on 4 May 2020).

49. Samsung Website. Washer with Vibration Reduction. Available online: https://www.samsung.com/us/home-appliances/ washers / front-load/wf5300-4-5-cf-front-load-washer-w--vrt-plus--2018--wf45n5300aw-us/ (accessed on 3 June 2020).

50. Amazon Website. Steady-Pad Anti-Vibration and Anti-Walk Washer and Dryer Pads Set. Available online: https://www.amazon. com/Sorbothane-Anti-Vibration-Anti-Walk-Washer-Machine/dp/B00536VQE0 (accessed on 4 May 2020).

51. GE Appliance Website. Washers Sensor Wash. Available online: https:// products.geappliances.com/appliance/gea-supportsearch-content? contentId=17818 (accessed on 4 May 2020).

52. DIY Network. How to Care for Different Types of Fabrics. Available online: https://www.diynetwork.com/how-to/maintenanceand-repair/cleaning/how-to-care-for-different-types-of-fabrics (accessed on 22 December 2020).

53. Home \& Garden Website. Smart Washing Machines Explained. Available online: https://www.which.co.uk/reviews/washingmachines/article/smart-washing-machines-explained-atSzX5S9PxPE (accessed on 24 May 2020).

54. Prime Appliance Website. GE Profile ${ }^{\mathrm{TM}}$ Frontload SmartDispense ${ }^{\mathrm{TM}}$ Laundry. Available online: https:/ / www.primeappliance. com/product/ge-profile-frontload-smartdispense-15-laundry-pedestal-white-spbd880jww-7449 (accessed on 24 May 2020).

55. Ebay Website. LG Washer \& Dryer Washing Liquid Dispenser Drawers. Available online: https://www.ebay.com/b/LG-WasherDryer-Washing-Liquid-Dispenser-Drawers/99697/bn_108249639 (accessed on 4 May 2020).

56. Barón, A.; de Castro, R.; Giménez, G. Circular economy practices among industrial EMAS-registered SMEs in Spain. Sustainability 2020, 12, 9011. [CrossRef]

57. Albæk, J.K.; Shahbazi, S.; McAloone, T.C.; Pigosso, D.C.A. Circularity evaluation of alternative concepts during early product design and development. Sustainability 2020, 12, 9353. [CrossRef]

58. Leal, J.M.; Pompidou, S.; Charbuillet, C.; Perry, N. Design for and from recycling: A circular ecodesign approach to improve the circular economy. Sustainability 2020, 12, 9861. [CrossRef] 